\title{
Death with dignity and the right to die: sometimes doctors have a duty to hasten death
}

\author{
Phillip J Miller University of Tennessee at Martin
}

\section{Author's abstract}

As the single most important experience in the lives of all people, the process and event of death must be handled carefully by the medical community. Twentieth-century advances in life-sustainng technology impose new areas of concern on those who are responsible for dying persons. Physicians and surrogates alike must be ready and willing to decide not to intervene in the dying process, indeed to hasten it, when they see the autonomy and dignity of patients threatened. In addition, the very ways we talk about death and dying need to come under scrutiny, and it is likely that our technical advances should be parallelled by equally arduous advances in the semantic and rhetorical approaches we take to death.

\section{I}

Those of us who are products of Western intellectual history and the Judaeo-Christian ethic have been nurtured on the idea that the unity-in-duality of human experience is a result of our animal/angelic natures; we are inseparably body and spirit. In addition, we have come to believe that a celebration of either half of our dual natures is a simultaneous celebration of the other half, that the essence of our humanity is an ecstasy that bridges the gap between the carnal and the ethereal.

In recognising our dual natures, we have also recognised that those ecstasy-producing experiences, those sublime and lofty moments of humanity, are themselves dual in nature; they are personal and private at the same time that they are vehicles for sharing. Thus sexual, spiritual, and intellectual consummations are private activities which provide fruits to be shared by the community. Such events as births, marriages, church services, art shows, concerts, and book publications all allow the community to have some share in the private experiences of its individual members, and at the same time serve as catalysts to inspire and encourage other individuals to engage in those private experiences.

\section{Key words}

Attitude to death; ethics, medical; technology, medical; terminal care.
The idea that our lives are both private and public has a strong foundation in Western literature. Every time I pick up one of the ten or so volumes of John Donne's sermons and meditations, I am struck by the incredible sense of community that he sees in his life as a Christian. In one of his most famous meditations, the one on the ringing of the church bells when a parishioner dies, he says that we should not inquire after the specific identity of the deceased when a deathknell is tolled. When death occurs, it is community and not individuality that should be celebrated because 'no man is an island'; each of us is 'a piece of the continent, a part of the main', and we are all diminished when part of our mainland is washed away. Therefore, 'ask not for whom the bell tolls; it tolls for thee' (1). By implication, of course, we are likewise increased when a new grain of sand washes ashore in the form of a birth.

Western literature from Geoffrey Chaucer to Ken Kesey is full of examples of the importance of community in the celebrations of life. But the attitudes towards, and definitions of, community are far different for Chaucer and his contemporaries than for Kesey and his. Chaucer's pilgrims are, collectively and individually, microcosmic reflections of the larger community, England. They may be from different social and economic classes, but they share an established and fixed view of the important spiritual and moral ends of life. They may violate the precepts imposed by their heritage, but they do so, for the most part, fully aware of what they are doing and willing to accept the consequences of their actions.

In One Flew Over the Cuckoo's Nest, the ward group may also be a microcosm of the larger community, but here it is a community turned topsy-turvy. Life on the ward is a barren and carefully controlled chaos whose hallmark is stratification. Rules have become ends in themselves, existing only to preserve a sterile environment in which patients can talk but never communicate, can smile but never laugh, can feel sadness and fear but never weep. In short, the ward is a well-oiled machine that does nothing even when it runs well; that functions simply for the sake of functioning. Not so Chaucer's world, where there is life, vitality, and purpose, where meaning is more important than ritual, where breakdowns are repaired 
by a laugh, a handshake, a kiss, or a shared drink.

As I see it, a sense of community as Chaucer and Donne envisioned it is no longer possible in modern industrial societies. Technology has created a kind of mobility, both physical and intellectual, that renders the traditional associations of community both meaningless and inappropriate. Indeed, it seems to me nearly absurd for urban newspapers to provide (or impose upon) their thousands of readers announcements of such things as weddings, births, and deaths, items which could not possibly interest people who feel no kinship to the names catalogued before them, people who commonly travel electronic airways worldwide for their news and entertainment. Such newspaper 'services' are an anachronistic attempt to convince us (or to reinforce our conviction) that we live in traditional communities.

However, there are people who touch our lives in profound ways, small communities if you will, that still can and should function in the traditional way. It is on one of these groups, health care professionals, and its response to the process and event of death, that I want to focus in this paper.

\section{II}

One of the problems of discussing death today is the variety of associations, nearly all of which are negative, that people make with it. Let me use as a modern touchstone of this negative view the comments by Professor Paul Ramsey in The Indignity of 'Death with Dignity'. Ramsey argues that the very phrase 'Death with dignity' is a contradiction in terms because death is the ultimate human indignity (2).

For theistic substantiation of this view, Professor Ramsey goes to the preacher in Ecclesiastes, from whom he quotes extensively in order to conclude that 'to deny the indignity of death requires that the dignity of man be refused also. The more acceptable in itself death is, the less the worth or uniqueness ascribed to the dying life' (2). For humanistic substantiation Ramsey again goes primarily to the scriptures in order to illustrate the traditional link between sin and death. The idea, of course, is that since death is punishment for sin, it is evil. No one, after all, could be expected to view punishment for sin or any other evil as anything but an indignity. Indeed, the whole purpose of punishment is to diminish dignity, to deny the punished some degree of autonomy accorded those not being punished. To those who would argue that death is simply a part of life, and therefore no more undignified than other parts of life, Ramsey responds by saying that we do not ennoble such common life experiences as disease, injury, congenital defects, murder, pillage, and rapine (2).

Ramsey is certainly accurate; no one would talk about murder or disease or any of the others as worthy human aims. But what he fails to note is that these experiences are 'part of life' only in a communal sense. (Robert S Morison and Leon Kass (3) have taken issue with Ramsey's conclusion. Many, indeed most, individuals are able to avoid them, even though no society can do so. However, what I intend by 'part of life' in this essay consists only of those things which may not be avoided by any individual - not those things which are collectively and publicly experienced.

In short, it is my contention that death is a good, as are all other aspects of human life that cannot be avoided by individuals: our births, our appetites, our instincts, our biological functions. This is not to say that these features of life cannot be, and often are, vitiated, corrupted, diverted, in all sorts of ways by all sorts of people. It is to say, however, that one of the duties of the medical professional is to aid patients in the achievement of that important, positive, endbeginning of human experience called death.

\section{III}

In The Counsels of Finitude, a perceptive and insightful essay on the sociological and individual importance of death, $\mathrm{H}$ Tristram Engelhardt, Jr discusses the relationship between the individual and the community concerning death. In his brief synthesis of the Platonic, Christian, and Hegelian attitudes towards human finitude, Engelhardt concludes that we humans should:

'act always to ensure that the general achievement of cultural values by humans is not precluded by the investment of resources and energies in postponing death. The ways in which health and disease can effect such achievement of value is a question properly and best addressed by medicine, but yet it is always addressed in terms of finite goals: the elimination of painful or premature deaths, never death itself' (4).

This comment was occasioned, at least in part, by Engelhardt's feeling that we do, in fact, invest too much of ourselves and our resources in postponing death. Why we do that is a difficult question; partly, I'm sure, for the science of it, for information about the dying process, medications, geriatrics, new technologies. But mostly, I suspect, out of a view that death is an unkind assault on poor old humanity, and something really should be done about it.

Again, Engelhardt's comment is perceptive. He notes that in Hegel's philosophical system individual finitude was 'not to be transcended in the person of the individual, but was to be resolved through the values of the community ... which outlives the individual'. Thus:

'the attempt to secure physical immortality is likely to obscure the legitimate goal of humanity, the pursuit of a rich but finite life. Considering the large amount of energy expended in medical research and treatment, the issue of balance is unavoidable. One must remember that one prolongs the length of life so that certain values can be realised, not for the mere 
prolongation itself (4).

Now, if these assertions about the prolongation of life and the importance of quality in life are valid at all, then it is clearly possible to find instances in which death should be hastened for the sake of quality, quality for both the individual and society.

Eric Cassell points in this direction of balance in an essay in which he argues that physicans have an obligation to urge patients to accept death rather than treatment. Dr Cassell uses one of his own patients, a woman near 80 whose final hospital stay and death took only nine days (the last three in a coma), to illustrate his position. Interestingly, he spends a good deal of time explaining that it is very hard for physicians to help patients accept death. 'The process strikes deep within and finds painful resonance in the doctor. It is difficult to find the proper words and yet absolute honesty is required - not honesty of words, like "cancer" or "death", which in any case mean more than they mean, but honesty of feelings' (5).

Certainly Dr Cassell is a sensitive and caring member of the health care profession, and certainly he is leaning in the right direction, but his comment strikes me as missing the mark because it fails to recognise the physician's duty, in some cases, to aid in hastening death rather than simply to urge the avoidance of treatment.

\section{IV}

Another serious problem in the philosophical and practical discussion of death is the 'right to die' issue. As I see it, the difficulty is that the phrase 'right to die' is at best problematic because of the associations that right suggests with duties and obligations. Let me give an example. Americans have decided that in America there is a right to food. But since food is traded on the free market, and since the free-market system imposes poverty on some citizens, the government was faced with a duty to devise a way to allow poor people to get their rightful food. Hence the creation of food stamps.

But there are numerous duties, obligations, and rights inherent in both sides of this complex of activities called feeding the country. Individuals have an obligation to both self and society (and I know some will disagree with me here) to eat foods that will promote health and abstain from foods that will decrease health. However, the government has a duty to protect its citizens from coercion in their choices of food. I have an obligation not to eat junk foods, but I certainly have a right to eat them, and the government has a duty to protect my right, even if it is at the same time providing me with the means to purchase my food.

But suppose $I$ am in a hospital, unable to eat normally, and must be nourished by some sort of intravenous line or nasogastric tube. As long as I am not mortally ill, the people responsible for my care have a duty (not just an obligation) to provide me with the best nutrition that technology allows, given my condition. If I say to them, 'feed me a blended mixture of Twinkies, sugar-coated cereal, and a soft drink', they have a duty not to do so because those foods are not nourishing.

The point is that eating is something that I must do to remain alive, and if I am unable to eat on my own, society has a series of duties and obligations to help me eat. In like manner, when it is time for me to die, the medical profession has a series of duties and obligations to aid me in achieving that end as an autonomous and dignified individual.

As Bernard Towers and others have argued, however, many physicians must feel that their only available means of fulfilling those duties and obligations is through the manipulation of technology (6). Their direct involvement with death seems bound by and limited to the occasional unplugging of some nasogastric tube or other device. Surely one reason for this perceived limitation is the long tradition in medicine that the physician not be cast, as Hans Jonas has said, in 'the role of a dispenser of death' (7).

Professor Jonas is surely right. I would certainly avoid any physician who had the reputation of being a dispenser of death. But the connotative value of Jonas's phrase is unfortunate. There is a qualitative difference between being a dispenser of death and being a physician who will help a patient in the difficult process of dying.

Leon Kass is also profoundly aware of the problem, and he is afraid that doctors might find themselves essentially removed from dying patients and forced to respond to the process of death 'under some form of external and uniform guidelines' (8). He feels that physicians have a duty 'to desist from useless procedures' for sustaining life, but his approach to the problem of death and dying is ambiguous. $\mathrm{He}$ is very much against the proliferation of rules which alter and diminish the traditional trust-based doctor-patient relationship. But he absolutely wants to retain those rules which prohibit direct intervention in order to hasten death (8).

Let me say categorically and with sincerest respect for human dignity that, while I am not for killing, I absolutely believe that physicians must be willing, on occasion, to take an active role in the process of death. They must do this to stop suffering (and I am untroubled by such breezy and flippant comments as: ' $\mathrm{Oh}$, yes, eliminate suffering by eliminating the sufferer'), to protect autonomy, and to replace technology by real people in dying situations - in the belief that when I am breathing my last breath, it is better to be touched by a hand than violated by a tube. I want the process of death to be taken out of the control of machines and returned to people. We should, most assuredly, all be able to die, as we evacuate, ingest, respire, and procreate, with a sense of contentment and a feeling that what we are doing is in some small measure an affirmation of our 
humanity.

Certainly no care-provider or surrogate would philosophically hope to do harm to a patient or to diminish autonomy or dignity by mechanical intervention. But there is often a distinction between what one will pay philosophical lip service to, and what one intends on a practical level. Often, instead of patient benefits, care-givers in fact intend one or more of the following when they begin mechanical interventions.

1. To buy time until a decision can be reached about what to do.

2. To genuflect (almost reflexively) in the direction of established and time-honoured methods - this is simply what one does in this situation.

3. To avoid possible malpractice suits.

4. To try some new material or method - to gain knowledge.

Surrogates, too, often intend practical outcomes that are not articulated in the decision-making process. The following are reasons I have heard (sometimes almost confessionally) from people who acted as spokespersons for others, and it should be noticed that not one of them focuses directly on benefits to the patient.

1. I would have felt guilty if I had not urged the doctors to do everything possible.

2. I could not stand the thought that $\mathrm{X}$ might have known that we did not do everything possible.

3. I would not want that done to me, but I did not know for sure that $\mathrm{X}$ didn't want it done.

4. It just seemed awful not to do anything, and that was all they could do.

Thus, while it is seldom the intention of health care professionals or surrogates to harm incompetent patients, it is also seldom that the decision to use available technology is made solely for the benefit of the patient. In saying this I do not intend to suggest that, therefore, such decisions should be reversed more than likely they should not be. What I do intend is to urge both parties in the decision to examine motives, to talk freely about those motives, and to ask, finally, whether this intervention serves the autonomy, the comfort, and the dignity of the individual.

The point is that here, as in the case of competent patients, rights, duties, and obligations need to be considered carefully, with focus on the right of the patient to die without undue efforts to forestall death, and the duties and obligations of the health care professional to aid, when necessary, the process of death.

When precisely the doctor has a duty or obligation to hasten death (to kill, if you prefer), I do not know. I can only generalise by saying that patients have a right to die as dignified, thinking human beings and that most people would prefer that to dying as vegetables. Knowing when to act will be difficult for doctors, but surely they can handle the pressure, especially when the result will return some small measure of human dignity to the person participating in the event of his or her own death.

\section{V}

What I have tried to do in this short essay is say something about the way that modern technology has skewed our intellectual heritage and thereby altered our perceptions of the means and ends of life and death. That alteration is necessarily neither good nor bad; it is simply a fact of life in the twentieth century. What we must do, however, is refuse to let our technology make us into automatons; we must stop bowing before it and allowing it to dictate the means to the ends of our lives; we must reclaim the process of dying.

Does this mean that we should reject the use of technology in health care? Certainly not; it is a powerful and wonderful tool, and many of the people closest to me are alive and healthy today only because of it. But people judged as incompetent and those clearly at the end of life are most easily victimised by technology because they do not have the means to deny its intrusions; we must make every effort to limit the number of these victims.

One of the new moral dilemmas imposed by advances in technology is how to handle people who have become its accidental victims, the Karen Ann Quinlans of the world. It is my contention that we must be willing and prepared to take an active role in the dying process of certain people, and we must be so disposed in order to avoid the more heinous calamity of becoming prolongers of respiring non-life. Certainly our medical professionals need to make every effort to allow meaningful and significant life (and of course this needs careful definition) to continue. But when that is not possible, we need to make every effort to ensure that death will occur.

As Joseph Fletcher has said: 'The classical deathbed scene, with its loving partings and solemn last words, is practically a thing of the past. In its stead is a sedated, comatose, betubed object, manipulated and subconscious, if not subhuman' (9). We all have an interest in this sad state of affairs, and we all have various duties and obligations to see to it that such circumstances occur far less frequently than they do.

\section{Acknowledgement}

I would like to thank the National Endowment for the Humanities and The University of Tennessee at Martin for partial support for the completion of this article.

Phillip Miller BA BS MA AD was educated at Indiana University, Idaho State University, and the University of Wisconsin. He has been the recipient of grants from the National Endowment for the Humanities to do research 
at the University of Florida, Indiana University, and the University of Virginia.

\section{References}

(1) Donne J. Devotions upon emergent occasions. London, 1624.

(2) Ramsey P. The indignity of 'death with dignity'. In: Steinfels $\mathrm{P}$, Veatch $\mathrm{R} \mathrm{M}$, eds. Death inside out: the Hastings Center report. New York: Harper and Row, 1974: 81-96.

(3) Morison R S. In: Steinfels P, Veatch R M, eds. Death inside out: the Hastings Center report. New York: Harper and Row, 1974: 97-100; Kass L, in the same book: 101-114.
(4) Engelhardt Jr H T. The counsels of finitude. In: Steinfels $\mathrm{P}$, Veatch $\mathrm{R} \mathrm{M}$, eds. Death inside out: the Hastings Center report. New York: Harper and Row, 1974: 115-125.

(5) Cassell E J. Permission to die. In: Behnke J A, Bok S. eds. The dilemmas of euthanasia. New York: Doubleday, 1975: 121-131.

(6) Towers B. Irreversible coma and withdrawal of life support: is it murder if the IV line is disconnected? Fournal of medical ethics 1982; 8: 203-205.

(7) Jonas H. The right to die. Hastings Center report 1978; 8: 31-36.

(8) Kass L. Ethical dilemmas in the care of the ill. Fournal of the American medical association 1980; 244: 1946-1949.

(9) Fletcher J. In: Downing A B, ed. Euthanasia and the right to death. London: Peter Owen, 1977: 65-66. 